\title{
Calabrian and Ionian: A proposal for the definition of Mediterranean stages for the Lower and Middle Pleistocene
}

\author{
1 Universita di Milano, Dipartimento di Scienze della Terra 'Ardito Desio', via Mangiagalli 34. 20133 Milano, Italy. \\ 2 Universita di Padova, Dipartimento di Geologia, Paleontologia e Geofisica, via Giotto 1, 35137 Padova, Italy. \\ 3 Universita di Bari, Dipartimento di Geologia e Geofisica, via Orabona 4, 70125 Bari, Italy. \\ 4 Universita di Palermo, Dipartimento di Geologia e Geodesia, corso Tukory 131, 90134 Palermo, Italy. \\ 5 Universita di Bologna, Dipartimento di Scienze della Terra e Geologico-Ambientali, Piazza di Porta San Donato, 1, 40126 Bologna, Italy.
}

\begin{abstract}
The need to standardise stratigraphical subdivisions of continuous marine sedimentary successions that outcrop for hundreds metres, using clearly defined points fixed in the field is strongly felt. A proposal is presented here to formalize regional stages for the Lower Pleistocene (Calabrian) and for the Middle Pleistocene (Ionian) in Italy. The sections are well exposed, carefully investigated using multiple criteria (an integrated stratigraphical approach) and located in the central part of the Mediterranean. This area is recognized worldwide as a classical region for the Neogene and the Pleistocene sequences. The terrestrial record is directly correlated with the deep-sea record, as determined from ODP Sites 653 (Tyrrhenian Sea), 963 (Sicily Channel) and 964 (Ionian Sea) from the central Mediterranean. The present formal proposal is consistent with the INQUA and ICS decision to define and correlate the Plio/Pleistocene boundary (GSSP at Vrica) within the Olduvai Subchron, at 1.81 My, the Lower/Middle Pleistocene boundary at the Matuyama/Brunhes reversal at 0.78 My and the Middle/ Upper Pleistocene boundary with the base of MIS 5 , approximately 0.13My. The present proposal also is consistent with the call for stage unit stratotypes that emphasize both the physical content of a stage and its boundaries (Hilgen et al., 2006).
\end{abstract}

\section{Introduction and historical background}

The Mediterranean, a semi-enclosed ocean basin that became isolated from the Indian Ocean in mid-Miocene times, was temporarily separated from the Atlantic Ocean during the Messinian salinity crisis. It then underwent important paleoceanographic changes after the early Zanclean deluge, with the deposition of climatically modulated, astronomically controlled sapropels (Hsü et al., 1973; Cita, 1975b; Van Couvering et al., 1976; Hilgen, 1991a; 1991b; Langereis and Hilgen, 1991; Lourens et al., 1996a). Actually, it behaves as an amplifier of the palaeoclimatic and palaeoceanographic signal (Cita and Mc Kenzie eds, 1999; 2000).
Open marine successions exposed near the shoreline in Southern Italy, especially in Sicily and Calabria, subject to uplift resulting from the still active geodynamic evolution, have been well known since the early days of stratigraphy.

Several marine stages have been defined as follows, in chronological order:

- Sicilian (Doderlein, 1872)

- Calabrian (Gignoux, 1910)

- Tyrrhenian (Issel, 1914)

- Milazzian (Deperet, 1918)

- Emilian (Ruggieri and Selli, 1949)

- Santernian (Ruggieri and Sprovieri, 1975)

- Crotonian (Ruggieri et al., 1977)

- Selinuntian (Ruggieri and Sprovieri, 1979).

The last was proposed as a super-stage in place of the Calabrian, and included from bottom to top the Santernian (cold), Emilian (temperate) and Sicilian (cold).

Palaeontology played a major role in the definition of all these stages, even during the 1970 s much attention was paid to the socalled 'northern guests' that included the pelecypod Arctica islandica in shallow water settings and the foraminifer Hyalinea balthica and the ostracod Cyteropteron testudo in the deep water settings. According to Berggren and Van Couvering (1974) ... 'In actual fact, only the Calabrian, and perhaps the Sicilian, have the requisite characteristics of a time-stratigraphic unit. Pleistocene marine is in need of a more suitable chronostratigraphic subdivision'.

Some of these stage names have been used internationally for several decades (cfr. Haq and Van Eysinga, 1987; 1998) and their names are well established in the literature, in particular the Calabrian and Tyrrhenian, but none meets the current requirements prescribed by the International Commission on Stratigraphy (cfr. Hedberg, 1976; Cowie, 1986; Salvador, 1994).

On the basis of a careful historical analysis, these stages have been considered mostly as 'nomina nuda' by Vai (1996).

Meanwhile the investigations of the Quaternary successions in the oceans, in ice cores, in lake deposits and in loess have drastically increased our knowledge whereas new techniques have improved the correlation potential in terms of time resolution and of credibility.

The application of the Milankovitch theory (1930) to the interpretation of ocean sediments recovered in deep sea cores, and the discovery that the isotopic composition of oxygen measured from the foraminifera shells, lead to the reconstruction of past climate fluctuations contributed to a revolutionary approach to palaeoclimatology (Hays et al., 1976). Cesare Emiliani was a pioneer in this field and first applied the method to an eastern Mediterranean piston core (Emiliani, 1955) and then to the classical Calabrian section of Le Castella (Emiliani et al., 1961, see below). 
The Plio/Pleistocene boundary in the Vrica section has been accepted (Aguirre and Pasini, 1985; Van Couvering ed., 1997), but that definition does not make reference to the Calabrian Stage. Recently the ICS decided that no global stages and related GSSPs will be accepted for the Pleistocene, but only regional stages within a time scale generated from the Marine Isotope Stratigraphy.

Purpose of the present paper is to present to the international community; 1) the various sections originally used to define the Mediterranean stages; 2) those selected as the most representative for a modern, agreed definition, investigated and cross-correlated by means of biostratigraphical, magnetostratigraphical, isotopic and orbitally-tuned stratigraphy, and occasionally tephrachronologically defined; and 3) those investigated from ODP continuously cored drill-sites from the same area. The complete dataset represents a very strong framework, in that it is intercalibrated and has a correlation potential that extends well beyond the classical Mediterranean area.

\section{Calabrian stage}

First stage of the Pleistocene Series. Its base coincides with the Pleistocene GSSP in the Vrica section. Its top with the Ionian boundary stratotype (criterion guide the Matuyama/Brunhes boundary).

Figure 1 shows the stratigraphical framework of the interval investigated. Only magnetostratigraphy and calcareous plankton biostratigraphy are considered here, but isotopic stratigraphy and orbitally-tuned stratigraphy have been applied to some of the ten sections in which the Calabrian has been differentiated, and to the ODP drill-sites. References for the sections are as follows (the numbers are those identifying the sections representing the Calabrian in Figure 2).

1. References for the VRICA section are given in Selli et al. (1977), Colalongo et al. (1980), Pasini and Colalongo (1982), Tauxe et al. (1983), Backmann et al. (1983), Aguirre and Pasini (1985), Bassett (1985), Howell et al. (1990), Azzaroli et al. (1996), Rio et al. (1996a) and Lourens et al. (1996b).
2. References for the LE CASTELLA section are given by: Emiliani et al. (1961), Smith (1969), Iaccarino (1975), Raffi and Rio (1980a) and Rio (1982).

3. References for the SANTA MARIA di CATANZARO locality are as follows: Gignoux (1910), Gignoux (1913), Bayliss (1969), Smith (1969), Selli (1970), Sprovieri et al. (1973) and Brolsma and Meulenkamp (1973).

4. References for the SINGA section include: Zachariasse et al. (1990), Zijderveld et al. (1991), Hilgen (1991), Lourens et al. (1992) and Lourens et al. (1996b).

All these sections are located in Calabria (Figure 2). Vrica and Singa are considered the best, the latter for the excellent palaeomagnetical and astrochronologically tuned record.

There are four sections in Sicily:

5. MONTE SAN NICOLA (where the Gelasian GSSP is defined). References include; Channel et al. (1992), Rio et al. (1994) and Rio et al. (1998).

6. The CAPO ROSSELLO section. The Rossello composite (Hilgen and Langereis, 1988; Langereis and Hilgen, 1991) is considered the template for the global Pliocene stratigraphy and includes the Miocene/Pliocene boundary GSSP recently approved in 2000 (Van Couvering et al., 2000). The same Miocene/Pliocene boundary stratotype was originally proposed in 1972 at the IGC in Montreal (Cita, 1975b). The Rossello composite also contains the Piacenzian GSSP and a level, within the Monte Narbone Formation, correlated with the Gelasian GSSP (Lourens et al., 1996a; Castradori et al., 1998). This formation extends upwards well above the Plio/Pleistocene boundary, duplicating the Vrica section (auxiliary stratotype) beneath the Capo Rossello lighthouse (Figure 3). References are as follows: Cita and Decima (1975), Gartner (1977), Rio et al. (1984); Di Stefano et al. (1993) and Caruso (2004).

7. The FICARAZZI site which is the type locality for the Sicilian Stage. References include: Doderlein (1872); Gradstein (1970); Sissingh (1973); Ruggieri and Sprovieri (1975); Buccheri (1984); Ruggieri et al. (1984); Di Stefano and Rio (1981) and Rio (1982).

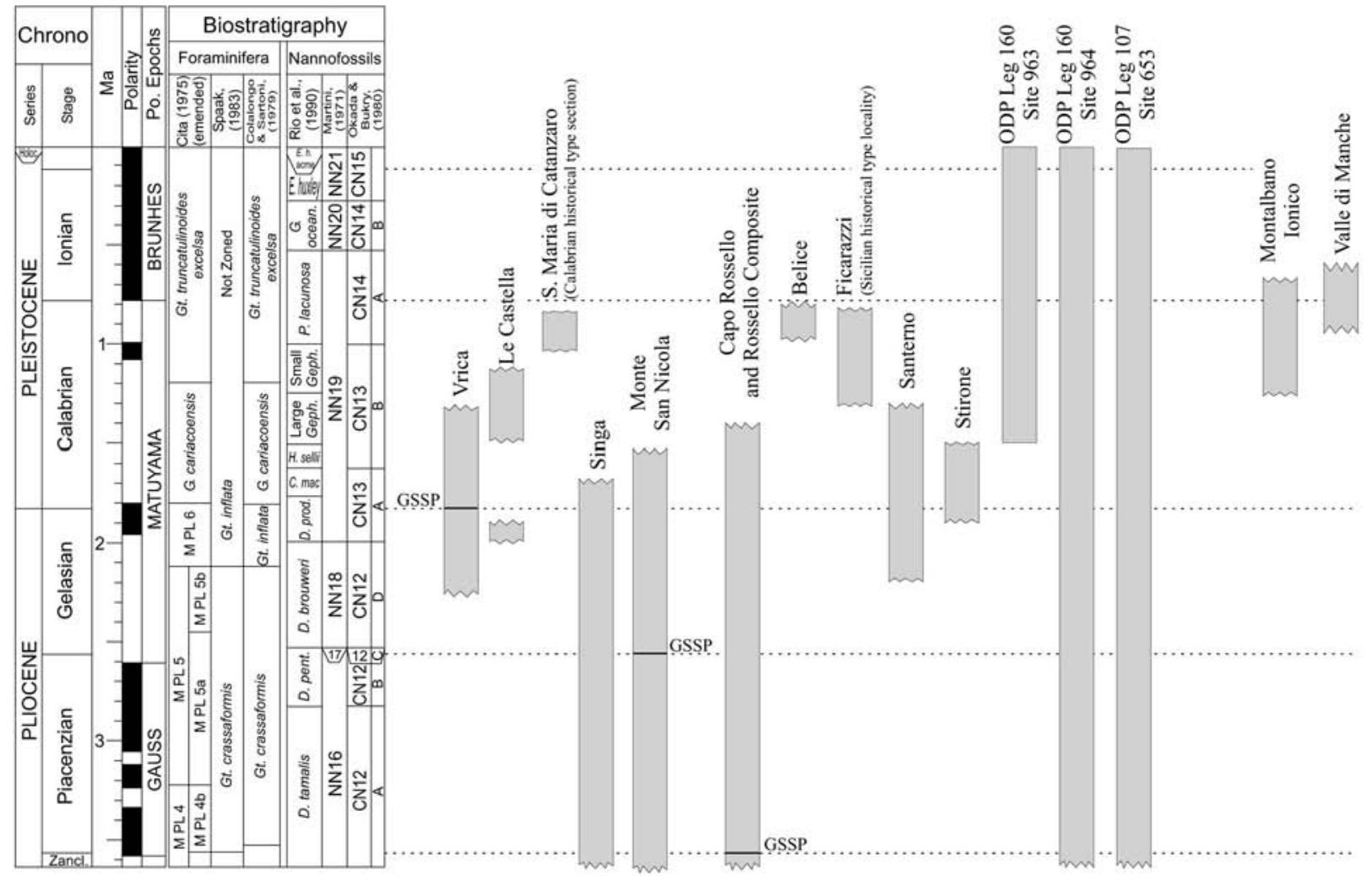

Figure 1 Stratigraphical framework showing the magnetostratigraphy and calcareous planktonic biostratigraphy of the time interval investigated. The stratigraphical range of the sections is indicative. 


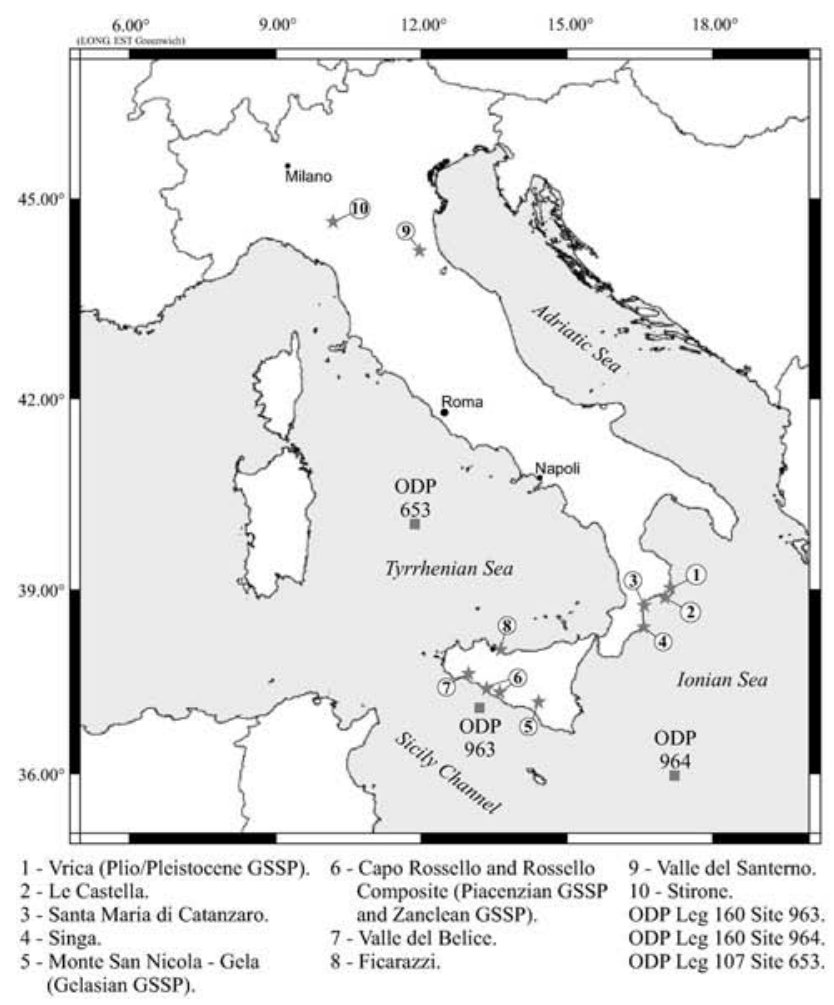

Figure 2 Italian sections and ODP drill-sites representing the Calabrian Stage.

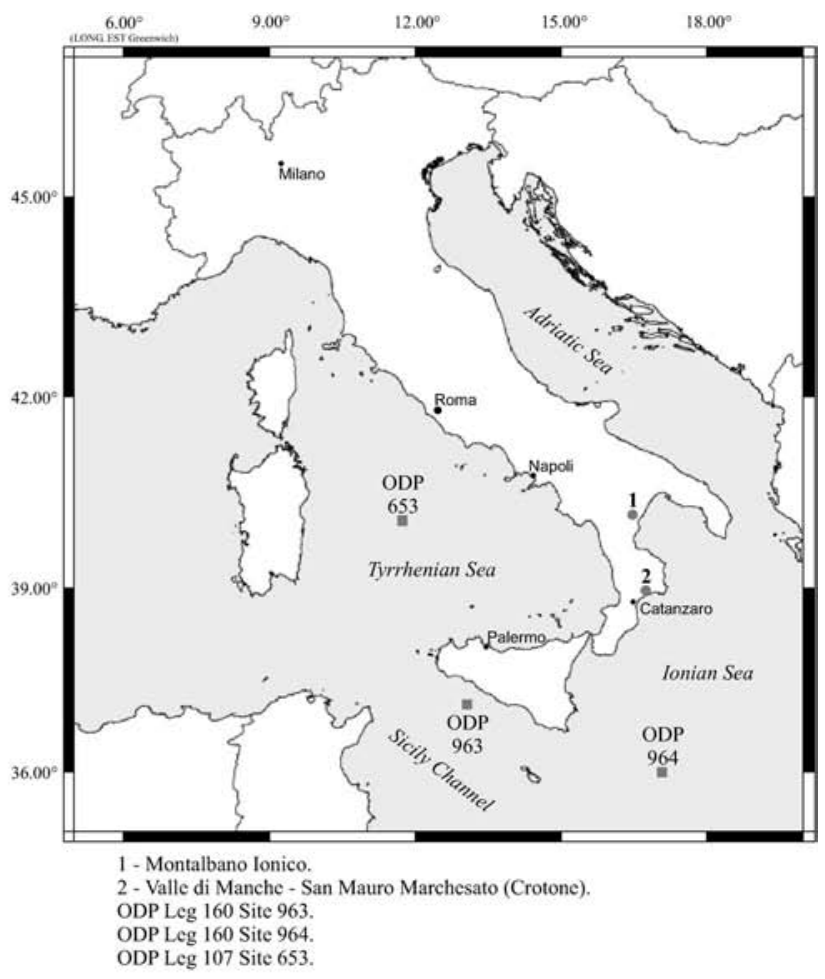

Figure 4 Italian sections and ODP drill-sites representing the Ionian Stage.

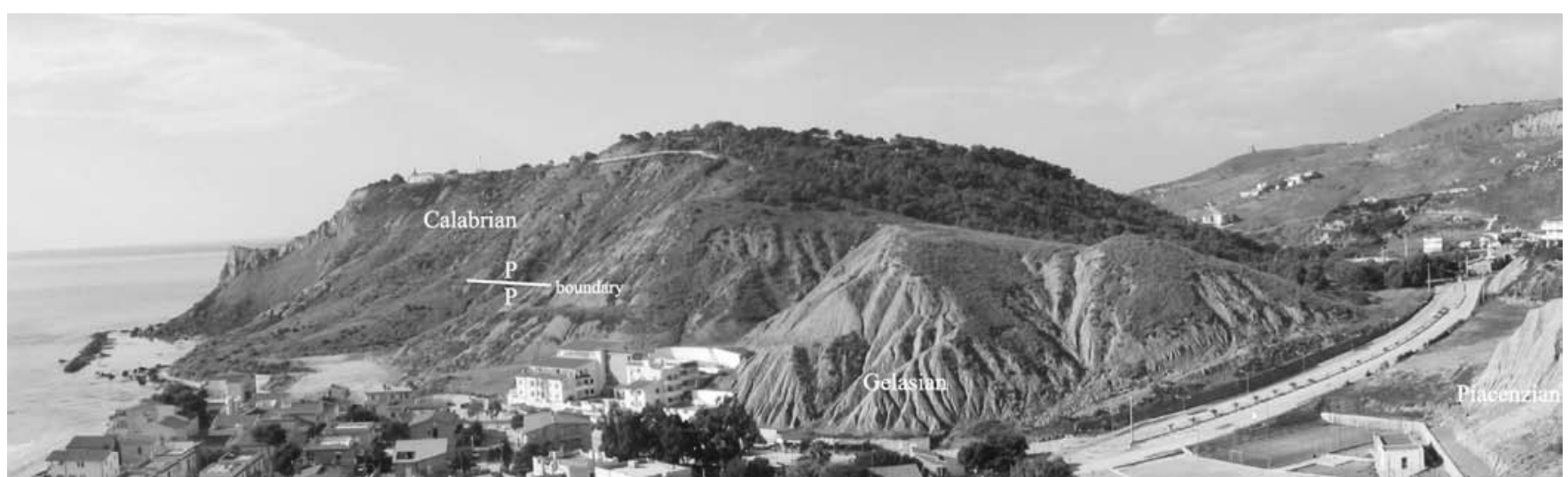

Figure 3 The Capo Rossello lighthouse segment section in which the Plio/Pleistocene boundary is well represented. It can be considered an auxiliary stratotype of the Vrica section.

8. The VALLE DEL BELICE site which is the locality for the Selinuntian Superstage: Ruggieri and Sprovieri (1979); Ruggieri et al. (1984); Buccheri (1985) and Di Stefano et al. (1991).

Important Calabrian sections located in northern Italy (Figure 2) include:

9. VALLE DEL SANTERNO. Type locality of the Santernian Stage (Ruggieri and Sprovieri, 1975). References include: Ruggieri (1954), Ruggieri (1957), Colalongo et al. (1974), Kukla et al. (1979), Pelosio et al. (1980) and Raffi and Rio (1980b).

10. STIRONE: Papani and Pelosio (1962), Bertolani Marchetti et al. (1979) and Pelosio et al. (1980).

The references for the ODP drill-sites are given under the Ionian below.

\section{Ionian Stage}

Second stage of the Pleistocene Series. Guiding criterion for its definition is the base of the Brunhes Chron. Its top is defined by the boundary stratotype of the third stage of the Pleistocene, for which the proposed criterion guide is the base of MIS 5.

Unlike the Calabrian, this is a fairly new name, although it has been presented several times in the last few years. The location of the Ionian sections and of the ODP drill-sites are shown in Figure 4.

Two land sections straddling the Brunhes-Matuyama boundary have been investigated in detail to date. The first one is the Montalbano Ionico section, located in the core of the Apennine foredeep, continuous and spectacularly exposed, although magnetostratigraphic control is presently lacking (Figure 5). The second one is that of Valle di Manche Nord, located near the San Mauro Marchesato village (Figure 6), a less spectacular outer shelf section that is well constrained in time on the basis of biomagnetostratigraphy integrated with astronomically tuned stratigraphy (stable oxygen isotopes and glacioeustatic trangressive-regressive cycles; Rio et al., 1996). Both sections were visited during several international meetings, including that organised by SEQS (Subcommission of European Stratigraphy of INQUA) in 2000. The Montalbano Ionico section represents the most suitable boundary stratotype of the Ionian, once provided with a reliable magnetostratigraphy. 


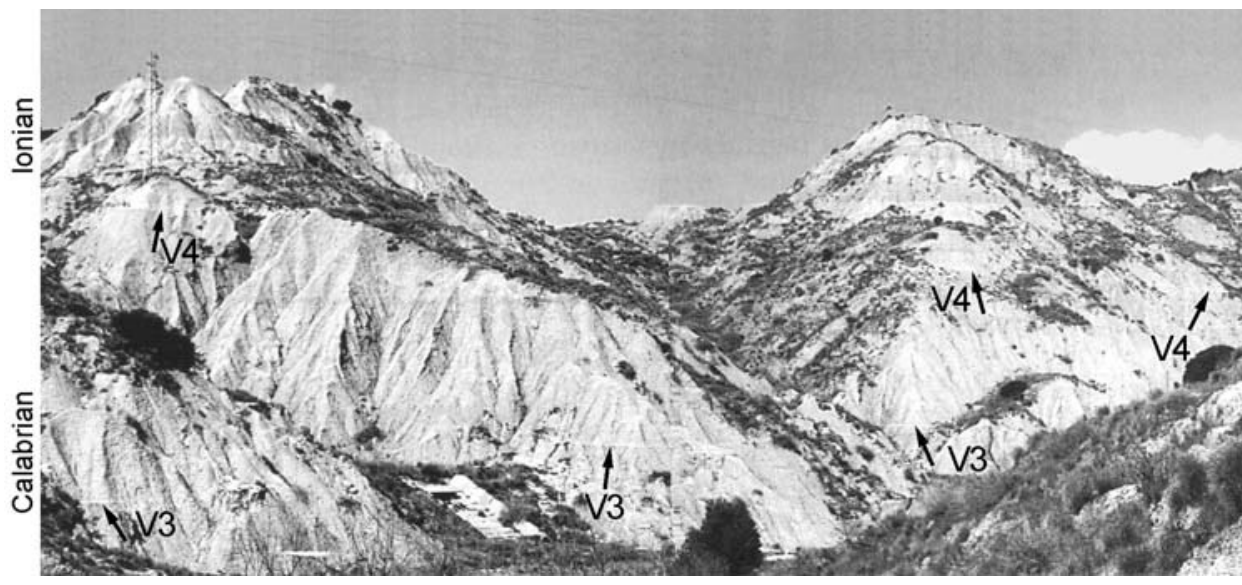

Figure 5 The Montalbano Ionico section (Ideale segment), in which the Calabrian/Ionian boundary will be defined. Arrows indicate the position of prominent ash layers V3 and V4.

netic reversal, as prescribed by ICS (Gradstein et al, 2004) and by INQUA (see below).This contrasts with the previous proposal which was to start the Middle Pleistocene close to the top of the Jaramillo Subchron, i.e. in correspondence with the so-called "mid Pleistocene climatic revolution" at the abrupt transition from the pre-glacial Quaternary to the glacial Quaternary. This event is very close to the change from the dominance of the $40 \mathrm{kyr}$ cycles to the $100 \mathrm{kyr}$ cycles (Hays et al., 1976; Shackleton et al., 1990; Berger et al., 1993; Berger, 1997). This proposal was in keeping with the practice of recognising the base of the Middle Pleistocene in the Mediterranean marine and continental records (Ruggieri et al., 1984; Rio et al., 1991) and was preferred by mammal paleontologists.

Three ODP drill-sites in the Ionian (Site 964) and Tyrrhenian (Site 653) basins and in the Sicily Channel (Site 963) can be very precisely correlated by means of calcareous plankton, palaeomagnetic stratigraphy, sapropel stratigraphy, isotopic stratigraphy, astronomically tuned stratigraphy and tephrachronology.

Of particular importance is Site 963, located in the Sicily channel, off - Capo Rossello. The high sedimentation rate, undisturbed succession and absence of turbidites, provides an ideal continuation of the Rossello composite, and contains a full expression of the Ionian stage, without any hiatuses.

1. References for the MONTALBANO IONICO section are as follows: Cita and Castradori (1994; 1995), Van Couvering (1995); Ciaranfi et al. (1997); Ciaranfi and D'Alessandro (2000; 2004); Ciaranfi et al. (2000); D'Alessandro et al. (2003); Maiorano et al. (2004) and Stefanelli (2004).

2. The VALLE DI MANCHE (San Mauro Marchesato) section references are: Rio et al. (1996b); Massari et al. (1999); Massari et al. (2001); Massari et al. (2002) and Capraro et al. (2005).

ODP SITE 963 (Sicily Channel). References include: Emeis, Robertson, Richter et al., (1996); Robertson, Emeis, Ricther and Camerlenghi (eds.) (1998); Di Stefano (1998) and Howell et al.(1998).

ODP Site 964 (Ionian Sea). References include: Emeis, Robertson, Richter et al (1996); Robertson, Emeis, Ricther and Camerlenghi (eds.) (1998); Sprovieri et al. (1998) and Howell et al. (1998).

ODP SITE 653 (Tyrrhenian Sea). References include: Kastens, Mascle et al. (1990); Rio et al. (1990a); Thunell et al. (1990); Rio et al. (1990b) and Glaçon et al. (1990).

\section{Discussion}

The present proposal results from a thorough discussion of all the data available after most shorebased studies deriving from ODP Legs 160 and 161 were published, and compared with the results obtained by a number of high-resolution stratigraphical studies carried out from measured sections in Sicily and Calabria. It is the third and final attempt to present a concrete proposal for the formalisation of regional stages for the Mediterranean classical area in order to stabilise the controversial chronostratigraphical subdivision (see discussion in Vai 1996).

A previous attempt was made after an International Workshop held in 1994, and reported by Cita and Castradori $(1994 ; 1995)$ and Van Couvering (1995). The workshop proposed identification of the 'cold' Calabrian with the Lower Pleistocene, and the "new" Ionian with the Middle Pleistocene, using the same sections proposed here. The main difference between the 1994 proposal and that presented here is that the basic criterion for the identification and correlation of the boundary between the two stages is the Matuyama/Brunhes mag-
Moreover, some biostratigraphers did hesitate in supporting the proposal because the most classical Calabrian historical type section, i.e. the Santa Maria di Catanzaro section of Gignoux (1910), would have to be ascribed to the new Ionian Stage according to this definition, in addition to overlapping with the Sicilian of Doderlein (1872) which had priority (Figure 1). The consequence was that the 1994 proposal was not further developed.

At this point, it is worth quoting from Gibbard (2003) ..."The major divisions of the Pleistocene, Lower, Middle and Upper, are agreed to be subseries (or subepochs), according to Richmond (1996) and conform to the International Stratigraphic Guide recommendations (Hedberg, 1976, p.10, 68). At present in the Pleistocene they remain undefined from stratotype localities in spite of the fact that in Europe at least these terms are used in a quasi-formal sense".

The need to define such events at GSSPs has been re-emphasised by Aubry et al (1999).

According to Gibbard (2003) in order to improve the situation the INQUA Working Group solicited opinions from a large number of concerned workers (Richmond 1996). The results proposed and approved at the XII INQUA Congress were summarized as follows (Anonymous, 1998) "As evolutionary biostratigraphy is not able to provide boundaries that are as globally applicable and time-parallel as are possible by other means, the Lower-Middle Pleistocene boundary should be taken provisionally at the Matuyama/Brunhes paleomagnetic reversal and the Middle-Upper Pleistocene boundary at the base of the deep-sea Oxygen Isotope Stage 5" (Figure 6).

Returning to the 1994 proposal (Cita and Castradori, 1994; 1995, Van Couvering, 1995) it should be stressed that it pre-dated:

a) the INQUA/ICS decision to use the Matuyama/Brunhes reversal as the major correlation tool for the Lower-Middle Pleistocene boundary (see discussion above and Head and Gibbard, 2005);

b) the trans-Mediterranean transect of continuously cored drillsites (ODP Legs 160-161; Emeis, Robertson, Richter, et al., 1996; Comas, Zahn, Klaus, et al., 1996, Robertson, Emeis, Richter and Camerlenghi (eds.) 1998; Zahn, Comas and Klaus (eds.) 1999) that greatly contributed to intercalibration of the Plio-Pleistocene deepsea record with the sequences exposed on the land.

\section{Conclusion}

The aim of this proposal is to clarify the confusion arising from the various and sometimes contrasting interpretations offered in the last several months on the chronostratigraphical versus climatostratigraphical, formal versus informal use of the term Quaternary (cfr. Pillans, 2004; Pillans and Naish, 2004; Gradstein et al., 2004; Gibbard et al., 2005; Aubry et al., 2005; Suguio et al., 2005; Salvador, $2006 \mathrm{a}, \mathrm{b})$ or what could be called the "Quaternary Quo Vadis" syndrome. 


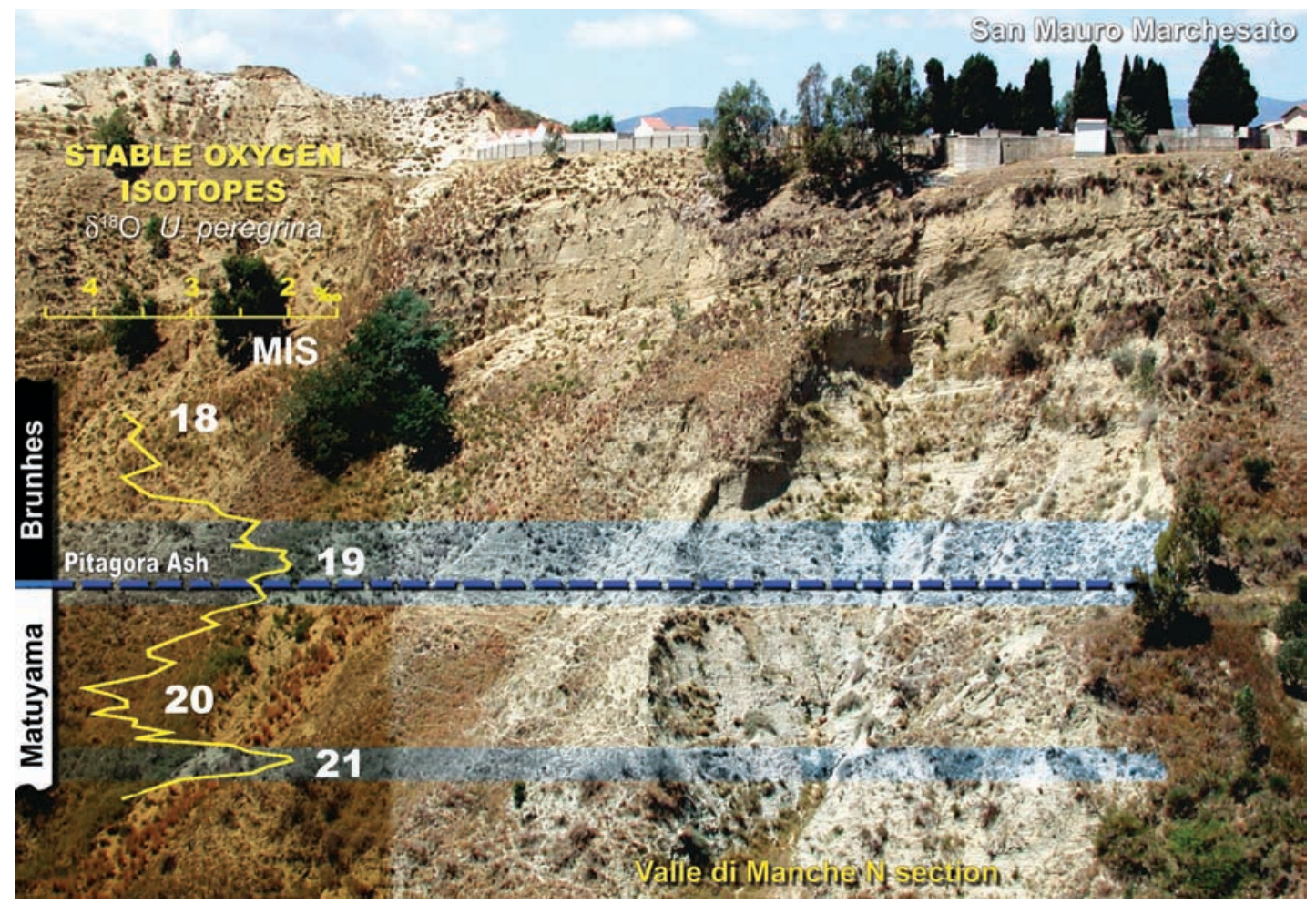

Figure 6 The coarsening and shallowing-upward middle-outer shelf Valle di Manche $N$ section, where the Matuyama-Brunhes magnetic reversal was confidently detected. The section, which is some 50 meters thick, spans from full MIS 24/22 glacial to late MIS 18 glacial. Above, further stratigraphy is preserved (see the prominent clinoforms just below the build area), however chronology becomes poor due to the inner shelfal setting. Thick bands in light blue indicate interglacial intervals based on the benthic foraminiferal $\delta^{18} \mathrm{O}$ record. Position of the Brunhes-Matuyama boundary (middle MIS 19) is easily recognizable in the field, as it occurs close to a prominent ash layer (Pitagora Ash, here indicated by the blue dashed line).

The sections presented are well exposed, carefully investigated using multiple criteria (a fully integrated stratigraphy) and located in the central part of the Mediterranean, an area recognised globally a classical reference area for the Neogene and for the Pleistocene. In this region the terrestrial record can be directly correlated with that in the deep-sea, as achieved at ODP Sites 653 (Tyrrhenian Sea), 963 (Sicily Channel) and 964 (Ionian Sea). The present formal proposal is consistent with the INQUA and ICS decision to recognise the Plio/Pleistocene boundary (GSSP at Vrica) the basic criterion for definition and correlating within the Olduvai Subchron, at $1.81 \mathrm{My}$, the Lower/Middle Pleistocene boundary close to the Matuyama/Brunhes polarity reversal at $0.78 \mathrm{My}$ and the Middle/Upper Pleistocene boundary with the base of MIS 5, approximately $0.13 \mathrm{My}$.

A full report on the Calabrian and Ionian unit-stratotypes and their deep-sea equivalents, based on selected sections, is in preparation, and will follow shortly. The complete dataset is very strong within a well-constrained time frame and provides an excellent reference sequence for the Pleistocene Mediterranean marine successions.

\section{Acknowledgments}

The present proposal was conceived and outlined during a workshop of the Italian Commission on Stratigraphy held in Spoleto in September 2005, and discussed by M. B. Cita, chair of ISSC, with the ICS chair F. Gradstein and ISQS chair P. Gibbard in Paris in November 2005. We are grateful to them and to J. Van Couvering for the encouragement and for providing useful information on official documents. We thank also Sergio Bonomo that kindly supported us in the computer editing.

\section{References}

Aguirre, E. and Pasini, G., 1985, The Pliocene - Pleistocene Boundary: Episodes, v. 8/2, pp. 116-120.

Anonymous, 1988, Biostratigraphy rejected for Pleistocene subdivisions Episodes, v.11, pp. 228.

Aubry, M. P., Berggren, W.A.,Van Couvering, J. D. and Steininger, F., 1999, Problems in chronostratigraphy: stages, serie, unit and boundary stratotypes, global stratotype section and point and tarnished golden spikes. Earth Science Reviews, v. 46, pp. 99-148.

Aubry M.-P., Breggren W.A., Van Couvering J.A, McGowran B., Pillans B., Hilgen F.J., 2005, Quaternary: Status, rank, definition, survival. Episodes, v. 28/2, p. 118-120.

Azzaroli, A., Colalongo, M. L., Nakagawa, H., Pasini, G., Rio, D., Ruggieri, G., Sartoni, S. and Sprovieri, R., 1996, The Pliocene-Pleistocene boundary in Italy. in Van Couvering, J., ed, The Pliocene-Pleistocene boundary: Definition and Worlwide Correlation: Cambridge University Press, pp. $141-155$.

Backman, J., Shackleton, N.J. and Tauxe, L., 1983, Quantitative nannofossil correlation to open ocean deep-sea sections from Plio-Pleistocene boundary at Vrica, Italy: Nature, v. 304, pp. 156-158.

Bassett, M. G., 1985, Towards a "Common Language" in Stratigraphy: Episodes, v. 8/2, pp. 87-92

Bayliss, D., 1969, The distribution of Hyalinea baltica and Globorotalia truncatulinoides in the type Calabrian: Lethaia, v. 2, pp. 133-143.

Berger, W. H., 1997, Experimenting with Ice-Age Cycles in a Spreadsheet. Journal of Geoscience Education, v. 45, pp. 428-439.

Berger, W.H., Bickert, T., Schmidt, H., and Wefer, G., 1993, Quaternary oxygen isotope record of pelagic foraminifers: Site 806, Ontong Java Plateau, in Berger, W.H., Kroenke, L.W., Mayer, L.A., et al. eds, Proceedings of the Ocean Drilling Program, Scientific results, v. 130: College Station, Texas, Ocean Drilling Program, pp. 381-395.

Berggren, W.A., and Van Couvering, J.A., 1974, The Late Neogene. Elsevier, pp. 1-216

Bertolani Marchetti, D., Accorsi, C.A., Pelosio, G. and Raffi, S., 1979, Palynology and Stratigraphy on the Plio-Pleistocene sequence on the Stirone River (Northern Italy): Pollen et Spores, v. 21, pp. 149-167. 
Brolsma, M. and Meulekamp, J.E., 1973: Benthonic foraminiferal assemblages from the Calabrian deposits of Santa Maria di Catanzaro: Newsl. Stratigr., v. 3/1, pp. 1-24

Buccheri, G., 1984, Pteropods as climatic indicators in Quaternary sequences: a lower-middle Pleistocene sequence out-cropping in Cava Puleo (Ficarazzi, Palermo, Italy): Paleogeogr., Palaeoclimat., Palaeoecol., v. 45, pp. 75-86.

Buccheri, G., 1985, Osservazioni paleoclimatiche al limite Pleistocene inferiore-Pleisticene medio della foce del Belice (Sicilia sud-occidentale) mediante l'uso degli Pteropodi: Boll. Soc. Geol. It., v. 104, pp. 115-122.

Capraro, L., Asioli, A., Backman, J., Bertoldi, R., Channell, J.E.T., Massari, F. and Rio, D., 2005, Climatic patterns revealed by pollen and oxygen isotope records across the Matuyama/Brunhes Boundary in central Mediterranean (Southern Italy): Geological Society of London, Special Publications, v. 247, pp. 159-182.

Caruso, A., 2004, Climatic changes during Late Pliocene and Early Pleistocene at Capo Rossello (Sicily, Italy): response from planktonic foraminifera: in Coccioni R., Galeotti S., Lirer F., eds, Proceedings of the First Italian Meeting on Environmental Micropaleontology: Grzybowski Foundation Special publication, v. 9, pp. 17-36.

Castradori, D., Rio, D., Hilgen, F.J. and. Lourens L.J., 1998, The Global Standard Stratotype-section and Point (GSSP) of the Piacenzian Stage (Middle Pliocene): Episodes, v. 21, pp. 88-93

Channell, J., Di Stefano, E. and Sprovieri, R., 1992, Calcareous plankton biostratigraphy, magnetostratigraphy and paleoclimatic history of the Plio-Pleistocene Monte S. Nicola section (Southern Sicily): Boll. Soc. Paleont. It., v. 31, pp. 351-382.

Ciaranfi, N., D'Alessandro, A. and Marino, M., 1997, A candidate section for the Lower-Middle Pleistocene Boundary (Apennine Foredeep, Southern Italy): Proc. $30^{\circ}$ Int. Geol. Congr., v. 11, pp. 201-211.

Ciaranfi, N. and D'Alessandro, A., 2000, Infrapleistocenic sections in the Montalbano Jonico area and the potential GSSP for the Lower-Middle Pleistocene in the Bradano Trough: Meeting 2000 of the SubCommission on European Quaternary Stratigraphy (SEQS), Bari (Italy) 25-29 september, v. Field trip guide, pp. 1-21

Ciaranfi, N. and D'Alessandro, A., 2004, Overview of the Montalbano Jonico area and section: a proposal for a boundary stratotype for the lowermiddle Pleistocene, Southern Italy Foredeep: Quaternary International, v 131 , pp. 5-10.

Ciaranfi, N., D’Alessandro, A., Girone, A., Maiorano, P., Marino, M., Soldani, D. and Stefanelli, S., 2000, Pleistocene sections in The Montalbano Jonico area and the potential GSSP for Early-Middle Pleistocene in the Lucania Basin (Southern Italy), in Ciaranfi, N., Pasini, G. and Rio, D. eds, The meeting on the Plio/Pleistocene boundary and the Lower/Middle Pleistocene transition: type areas and sections (Bari, 25-29 september 2000): Memorie di Scienze Geologiche, Padova, v. 53, pp. 67-83.

Cita, M.B., 1975a, Planktonic foraminiferal biozonation of the Mediterranean Pliocene deep sea record. A revision: Rivista Italiana di Paleontologia e Stratigrafia, v. 81. pp. 527-544.

Cita, M.B., 1975b, The Miocene/Pliocene Boundary: History and definition. In Saito, T. and Burkle, L.H., eds. Late Neogene Epoch Boundaries: New York, Micropaleontology Press, Spec. Publ., v. 1, pp. 1-30.

Cita, M.B. and Castradori, D., 1994, Workshop on marine sections from the Gulf of Taranto (Southern Italy) usable as potential stratotypes for the GSSP of the Lower, Middle and Upper Pleistocene. Il Quaternario, v. 7, pp. 677-692.

Cita, M.B. and Castradori, D., 1995, Rapporto sul Workshop "Marine sections from the Gulf of Taranto (Southern Italy) usable as potential stratotypes for GSSP of the Lower, Middle and Upper Pleistocene". Boll.Soc.Geol.It., v.114, pp. 319-336.

Cita, M.B. and Decima, A., 1975, Rossellian: proposal for a superstage for the marine Pliocene: Proc. VI Congress RCMNS, pp. 217-227.

Cita, M.B. and Mc Kenzie J., eds., 1999, Cycles, events, sea levels in Messinian times. Proceedings of the International Conference "Neogene Mediterranean Paleoceanography" Erice september 1977: Mem. Soc. Geol. It., v. 118, pp. 1-159.

Cita, M.B. and Mc Kenzie J., eds, 2000, Mediterranean Sapropels: Observations, Interpretations and Models. Palaeogeography, Palaeoclimatology, Palaeoecology, v. 158/3-4, pp. 150-402.

Colalongo, M.L., Elmi, C. and Sartoni, S., 1974, Stratotypes of the Pliocene and Santerno rivers section: Mém. B.R.G.M., V Congrès Néog. Medit., Lyon, v. 2/78, pp. 603-624.

Colalongo, M.L., Pasini, G. and Sartoni, S., 1980, Remarks on the Neogene/Quaternary boundary and the Vrica section: Preprint 26th Int. Geol. Congr., Paris, pp. 1-40
Colalongo, M.L. and Sartoni, S., 1979, Schema biostratigrafico per il Pliocene e il basso Pleistocene in Italia: Roma Contributo Preliminare Carta Neotettonica díltalia ,pp. 645-654.

Comas, M.C., Zahn, R., Klaus, A., et al., 1996, Proceedings of the Ocean Drilling Program, Initial Reports. College Station TX, v.161, pp.113-177.

Cowie J.W., 1986, Guidelines for boundary stratotypes. Episodes, v. 9/2, pp.78-82.

D’Alessandro, A., La Perna, R. and Ciaranfi, N., 2003, Response of macrobenthos to changes in palaeoenvironments in the Lower-Middle Pleistocene (Lucania Basin, Southern Italy): Il Quaternario, Italian Journnal of Quaternary Sciences, v. 16, pp. 167-182.

Dèpèret, C., 1918, Essai de coordination chronologique des temps quaternaires. C.R. Acad. Sc., v. 166, 12, pp. 480-486, Paris.

Di Stefano, E., 1998, Calcareous nannofossil quantitative biostratigraphy of Holes 969E and 963B (Eastern Mediterranean). in Robertson, A.H.F., Emeis, K.C., Richter, C. and Camerlenghi, A., eds, Proc. ODP, Sci. Results, v. 160, pp. 99-112. College Station, TX (Ocean Drilling Program).

Di Stefano, E. and Rio, D., 1981, Biostratigrafia a nannofossili e biocronologia del Siciliano nella localita' tipo di Ficarazzi (Palermo - Sicilia): Acta Naturalia de l'Ateneo Parmense, v. 17, pp. 97-111.

Di Stefano, E., Sprovieri, R. and Scarantino, S., 1991, Biostratigrafia e paleoecologia della sezione intrapleistocenica di Casa Parrino (Foce del Belice, Sicilia sud occidentale): Il Naturalista Siciliano, s. IV, v. XV, pp. 115-148.

Di Stefano, E., Sprovieri, R. and Caruso, A., 1993, High resolution biochronology in the Monte Narbone Formation of the Capo Rossello section and the Mediterranean first occurrence of Globorotalia truncat ulinoides: Riv. It. Paleont. Strat., v. 99, 3, pp. 357-370.

Doderlein, P., 1872, Note illustrative della carta geologica del Modenese e del Reggiano: Memoria III, pp. 74, Modena.

Emeis, K.-C., Robertson, A.H.F., Ricther, C. et al., 1996, Proceedings of the Ocean Drilling Program, Initial Reports, v. 160, College Station, TX (Ocean Drilling Program).

Emiliani, C., 1955, Pleistocene temperatures. Jour. Geol., v. 63, pp. 538-578.

Emiliani, C., Mayeda, T. and Selli, R., 1961, Paleotemperature analysis of the Plio-Pleistocene section at Le Castella, Calabria, southern Italy: Geol. Soc. Am. Bull., v. 72, pp. 679-688.

Gartner, S., 1977, Calcareous nannofossil biostratigraphy of the Monte Narbone Formation at the type-locality of the Rossellian superstage: Riv. Ital. Paleontol. Stratigr., v. 83, pp. 179-190.

Gibbard, P.L., 2003, Definition of the Middle-Upper Pleistocene boundary. Global and Planetary change, v. 36, pp. 201-208.

Gibbard, P.L., Smith, A.G., Zalasiewicz, J.A., Barry, T.L., Cantrill, D., Coe A.L., Cope, J.C.W., Gale, A.S., Gregory, F.J., Powell, J.H., Rawson, P.F., Stone, P. and Waters, C.N., 2005, What status for the Quaternary. Boreas, v. 34, pp.1-6.

Gignoux, M., 1910, Sur la classification du Pliocène et du Quaternarie dans l'Italie du Sud: C.R. Acad. Sc., seance 29, v. 150, pp. 841-844.

Gignoux, M., 1913, Les formations marines pliocènes et quaternaires de l'Italie du Sud et de la Sicile. Ann. Univ. Lyon, v. 36, pp. 1-633.

Glaçon, G., Rio, D. and Sprovieri, R., 1990, Calcareous plankton PliocenePleistocene biostratigraphy in the Tyrrhenian sea (Western Mediterranean, Leg 107), in Kastens, K.A., Mascle, J., et al., eds., Proc. ODP Sc. Result., v. 107, pp. 683-693. College Station, TX (Ocean Drilling Program).

Gradstein, F.M., 1970, Foraminifera from the type Sicilian at Ficarazzi, Sicily (Lower Pleistocene): Kon. Ned. Ak. Weten. Proc., Ser. B. 73, 4, pp. 29, Amsterdam.

Gradstein, F.M., Ogg, J.G., Smith, A.G., Bleeker, W. and Lourens, L.J., 2004, A new Geological Time Scale, with special reference to Precambrian and Neogene: Episodes, v. 27, pp. 83-100.

Haq, B.U. and Van Eysinga, F.W.B., 1987, Geological Time table. Fourth, Revised Enlarged and Updated Edition. Elsevier, The Netherlands.

Haq, B.U. and Van Eysinga, F.W.B., 1998, Geological Time table. Fifth Revised Revision. Elsevier, The Netherlands.

Hays, J.D., J. Imbrie, and N.J. Shackleton, 1976, Variations in the Earth's orbit: Pacemakers of the ice ages, Science, v. 194, pp. 1121-1132.

Head, M.J. and Gibbard, P.L., 2005, An overview of Early-Middle Pleistocene transitions, and a recommendation for defining a boundary, in Head M.J. and Gibbard, P.L.,eds, 2005, Early Middle Pleistocene transitions: the land-ocean evidence, Geological Society Special publication, pp. 247.

Hedberg, D.H., 1976, International Stratigraphic Guide-A guide to stratigraphic classification, terminology and procedure: John Wiley and Sons, New York, pp. 1-200. 
Hilgen, F.J., 1991a, Astronomical calibration of Gauss to Matuyama sapropels in the Mediterranean and implication for the Geomagnetic Polarity Time Scale. Earth and Planetary Science Letters, v. 104, pp. 226-244.

Hilgen, F.J., 1991b, Extension of the astronomically calibrated (polarity) time scale to the Miocene/Pliocene boundary. Earth and Planetary Science Letters, v. 107, pp. 349-368.

Hilgen, F.J. and Langereis, C.G., 1988, The age of the Miocene-Pliocene boundary in the Capo Rossello area (Sicily): Earth and Planetary Science Letters, v. 91, pp. 214-222.

Hilgen, F.J. and Langereis, C.G., 1993, A critical evaluation of the Miocene/Pliocene boundary as defined in the Mediterranean: Earth and Planetary Science Letters, v. 118, pp. 167-179.

Hilgen, F.J., Brinkhuis, H. and Zachariasse, W.J., 2006, Unit stratotypes for global stages: The Neogene perspective: Earth-Science Reviews, v. 74, pp. 113-125.

Howell, M. H., Rio, D. and Thunell, R., 1990, Laminated sediments from the Vrica section (Calabria, southern Italy): evidence for Plio-Pleistocene warming and cooling trends in the Mediterranean region: Paleogeography, Paleoclimatology, Paleoecology, v. 78, pp. 195-216.

Howell, M., Thunell, R., Di Stefano, E., Sprovieri, R., Tappa, E. and Sakamoto, T., 1998, Stable isotope chronology and paleoceanographic history of Sites 963 and 964, Eastern mediterranean Sea, in Robertson, A.H.F., Emeis, K.C., Richter, C. and Camerlenghi, A. eds, Proc. ODP, Sci. Results, v. 160, pp. 167-180. College Station, TX (Ocean Drilling Program).

Hsü, K. J., Ryan, W.B.F. and Cita, M.B., 1973, Late Miocene dessiccation of the Mediterranean. Nature, v. 242, pp. 240-244.

Iaccarino, S., 1975, New data on the proposed Plio-Pleistocene boundary type-section of Le Castella (Calabria Italy). II Planktonic and significant benthonic Foraminifera: LíAteneo Parmense, Acta Naturalia, v. 11/3: pp. 449-465

Issel, A., 1914, Lembi fossiliferi quaternari e recenti nella Sardegna meridionale: Accademia Nazionale dei Lincei 5 e ser., 23, pp. 759-770.

Kastens, K.A., Mascle, J., et al., 1990, Proc. ODP, Sci. Results, v. 107. College Station, TX (Ocean Drilling Program)

Kukla, G., Collins, B.P. and Bender, M.L., 1979, Radiometric age of the Arctica islandica boundary in Italy: 2 m.y: Ann. Géol. Pays Hellén., T. hors sèrie, 1979, VII th Inter. Congr. On Mediterranean Neogene, Athens, pp. 699-709.

Langereis, C.G., and Hilgen, F.J., 1991, The Rossello composite: a Mediterranean and global reference section for the Early to early Late Pliocene. Earth and Planetary Science Letters, v. 104, pp. 211-225.

Lourens, L.J., Antonarakou, A., Hilgen, F.J., Van Hoof, A.A.M., VergnaudGrazzini, C. and Zachariasse, W., 1996a, Evaluation of the Plio-Pleistocene astronomical timescale: Paleoceanography, v. 11, pp. 391-413.

Lourens, L.J., Hilgen, F.J., Raffi, I. and Vergnaud-Grazzini, C., 1996b, Early Pleistocene chronology of the Vrica section (Calabria, Italy): Paleoceanography, v. 11/6, pp. 797-812.

Lourens, L.J., Gudjonsson, L. and Zachariasse, W.J., 1992, Late Pliocene to early Pleistocene astronomically forced sea surface productivity and temperature variations in the Mediterranean: Marine Micropaleont., v. 19, pp. $49-78$

Maiorano, P., Marino, M., Di Stefano, E. and Ciaranfi, N., 2004, Calcareous nannofossil events in the Lower-Middle Pleistocene transition at the Montalbano Jonico section and ODP Site 964: calibration with isotope and sapropel stratigraphy: Rivista Italiana di Paleontologia e Stratigrafia, v. 110/2, pp. 547-557.

Martini, E., 1971, Standard Tertiary and Quaternary calcareous nannoplankton zonation: Roma, Proceedings II Planktonic Conference, 1970, v. 2, pp. 738-785.

Massari, F., Rio, D., Sgavetti, M., Asioli, A., Backman, J., Capraro, L., D'Alessandro, A., Fornaciari, E. and Prosser, G., 2001, The middle Pleistocene of the Crotone Basin, in Ciaranfi, N., Pasini, G. and Rio, D., eds, The meeting on the Plio/Pleistocene boundary and the Lower/Middle Pleistocene transition: type areas and sections (Bari, 25-29 september 2000): Memorie di Scienze Geologiche, Padova, v. 53, pp. 85-112.

Massari, F., Rio, D., Sgavetti, M., Prosser, G., D’Alessandro, A., Asioli, A., Capraro, L., Fornaciari, E. and Tateo, F., 2002, Interplay between tectonics and Glacio-eustasy, Pleistocene of the Crotone Basin, Calabria (southern Italy): Bulletin of the American Geological Society, v. 114, pp. 11831209.

Massari, F., Sgavetti, M. and Rio, D., 1999, Composite sedimentary record of falling stages of Pleistocene gladio-eustaic cycles in a shelf setting (Crotone basin, south Italy): Sedimentary Geology, v.127, pp. 85-110.

Milankovitch, M., 1930, Matematische Klimalehre und astronomische Theorie der Klimmaschwankungen: Handbuch der Klimatologie, Bd 1, Teil A, Borntrager, Berlin, pp.1-176.
Okada, H., and Bukry, D., 1980, Supplementary modification and introduction of code numbers to the low-latitude coccolith biostratigraphic zonation: Marine Micropaleontology, v. 5, pp. 321-325.

Papani, G. and Pelosio, G., 1962, La serie Plio-Pleistocenica del T. Stirone (Parmense occidentale): Boll. Soc. Geol. It., v. 81/4, pp. 293-335.

Pasini, G. and Colalongo, M.L., 1982, Status of research on the Vrica section (Calabria , Italy), the proposed Neogene/Quaternary boundary-stratotipe section: in 1982 Report at XI INQUA Congress, Pitagora-Tecnoprint. pp $1-75$

Pelosio, G., Raffi, S. and Rio, D., 1980, The Plio-Pleistocene boundary controversy, Status in 1979 at the light of International Stratigraphic Guide: Vol. dedicato a Sergio Venzo, pp. 131-140, Grafiche steep, Parma.

Pillans, B., 2004, Proposal to redefine the Quaternary, in Revision of the Geological Time Scale: Quaternary Perspectives, v. 14, pp. 125.

Pillans, B., and Naish., T., 2004, Defining the Quaternary. Quaternary Science Rewiew, v. 23, pp. 2271-2282.

Raffi, I. and Rio, D., 1980a, Nuove osservazioni sulla distribuzione del nannoplancton calcareo nella serie di Le Castella (Calabria): Palentologia Stratigrafica ed Evoluzione. Quaderno n. 1, pp. 181-186.

Raffi, I. and Rio, D., 1980b, Nannoplancton Calcareo del Pliocene SuperiorePleistocene Inferiore della Serie del Fiume Santerno: Palentologia Stratigrafica ed Evoluzione. Quaderno n. 1, pp. 187-195.

Richmond, G.M.,1996, The Inqua approved provisional Lower-Middle Pleistocene boundary: in Turner C.: The early middle Pleistocene in Europe, pp. 319-326, Balkema, Rotterdam.

Rio, D., 1982, The fossil distribution of Coccolithophore Genus Gephyrocapsa Kamptner and related Plio-Pleistocene chronostratigraphic problems, in Prell W.L., Gardner, J.V. et al., Initial Reports of the Deep Sea Drilling Project, v. 68, pp. 325-343

Rio, D., Backman, J. and Raffi, I., 1996a, Calcareous nannofossil Biochronology and the Pliocene - Pleistocene Boundary, in Van Couvering, J., ed, The Pliocene-Pleistocene boundary: Definition and Worlwide Correlation: Cambridge University Press, pp. 63-78.

Rio, D., Channell, J.E.T., Massari, F., Poli, M.S., Sgavetti, M., D’Alessandro, A. and Prosser, G., 1996b, Reading Pleistocene euastasy in a tectonically active siliciclastic shelf setting (Crotone peninsula, southern Italy): Geology, v. 24, pp. 743-746.

Rio, D., Raffi, I. and Villa, G., 1990a, Pliocene-Pleistocene calcareous nannofossil distribution patterns in the Western Mediterranean, in Kastens, K.A., Mascle, J., et al., eds, Proc. ODP Sc. Result., v. 107, pp. 513-532. College Station, TX (Ocean Drilling Program).

Rio, D., Sprovieri, R. and Channell, J., 1990b, Pliocene - early Pleistocene chronostratigraphy and the Tyrrhenian deep-sea record from Site 653, in Kastens, K., Mascle, J. et al., eds, Proceedings of the Ocean Drilling Program Scientific Results, v. 107, pp. 705-714. College Station, TX (Ocean Drilling Program).

Rio, D., Sprovieri, R., Castradori, D. and Di Stefano, E., 1998, The Gelasian Stage (Upper Pliocene): A new unit of the global standard chronostratigraphic scale: Episodes, v. 21, pp. 82-87.

Rio, D., Sprovieri, R., and Di Stefano, E., 1994, The Gelasian Stage: a proposal of a new Chronostratigraphic Unit of the Pliocene Series: Riv. It Paleont. Strat., v. 100, 1, pp. 103-124.

Rio, D., Sprovieri, R. and Raffi, I. 1984, Calcareous Plankton Biostratigraphy and Biochronology of the Pliocene - lower Pleistocene succession of the Capo Rossello area: Marine Micropaleontology, v. 9, pp. 135-180.

Rio, D., Sprovieri, R., Thunell, R., 1991, Pliocene-lower Pleistocene chronostratigraphy: a re-evaluation of Mediterranean type sections: Geol. Soc. Am. Bull., v. 103, pp. 1049-1058.

Robertson, A.H.F., Emeis, K.C., Ricther, C., Camerlenghi, A., et al., 1998 Proc. ODP, Sci. Results, 160. College Station, TX (Ocean Drilling Program).

Ruggieri, G., 1954, La limite entre Pliocêne et Quaternaire dans la série PlioPleistocêne du Santerno: Atti Congr. Gèol. Int. Alger 1952, v. 3, pp. 235240.

Ruggieri, G., 1957, Nuovi dati sul contatto Pliocene-Calabriano nella sezione del Santerno (Imola): Giorn. Geol., v. 26, pp. 1-8.

Ruggieri, G., Rio, D. and Sprovieri, R., 1984, Remarks on the chronostratigraphic classification of Lower Pleistocene: Boll. Soc. Geol. It., v.103, pp. 251-259.

Ruggieri, G. and Selli, R., 1949, Il Pliocene ed il Postpliocene dell'Emilia: Giorn. Geol. (2), v. 20, pp. 1-14.

Ruggieri, G. and Sprovieri, R., 1975, La definizione dello stratotipo del Piano Siciliano e le sue conseguenze: Riv. Miner. Siciliana, v. 26, pp. 151-153.

Ruggieri, G. and Sprovieri, R., 1979, Selinuntiano, nuovo superpiano per il Pleistocene inferiore: Boll. Soc. Geol. Ital., v. 96, pp. 197-802. 
Ruggieri, G., Unti, A., Unti, M. and Moroni, M.A., 1977, La calcarenite di Marsala (Pleistocene inferiore) e i terreni contermini: Boll. Soc. Geol. It., v. 74, pp. 1623-1657.

Salvador A. (ed), 1994. International Stratigraphic Guide, 2nd Edition, GSA, $214 \mathrm{pp}$.

Salvador, A., 2006a, The Tertiary and the Quaternary are here to stay: AAPG Bulletin, v. 90, 1, pp. 21-30

Salvador, A., 2006b, A stable Cenozoic geologic time scale is indispensable: Episodes, v. 29, n. 1, pp. 43-45

Selli, R., 1970, Calabrian: Giorn. Geol., v. 37, pp. 55-64.

Selli, R., Accorsi, C.A., Bandini Mazzanti, M., Bertolani Marchetti, D., Bonadonna, F.P., Borsetti, A.M., Cati, F., Colalongo, M.L., d'Onofrio, S., Landini, W., Menesini, E., Mezzetti, R., Pasini, G., Savelli, G. and Tampieri, R., 1977, The Vrica section (Calabria). A potential NeogeneQuaternary boundary stratotype: G. Geol., v. 41, pp. 181-204.

Shackleton, N.J., Berger, A., Peltier, W.R., 1990, An alternative astronomical calibration of the lower Pleistocene timescale based on ODP Site 677 Trans. R. Soc. Edinburgh: Earth Sc. v.81, pp. 251-261.

Sissingh, W., 1973, The ostracode fauna of the type Sicilian (Quaternary) deposits at Ficarazzi, Sicily: Proc. K. Nederl. Akad Wetenssh., v. 76, pp 341-357.

Smith, L.A., 1969, Pleistocene Discoasters at the stratotype of the Calabrian stage (Santa Maria di Catanzaro) and Le Castella, Italy: Gulf Coast Assoc. Geol. Soc. Trans., v. 19, pp. 579-583.

Spaak, P., 1983, Accuracy in correlation and ecological aspects of the planktonic foraminiferal zonation of the Mediterranean Pliocene: Utrecht Micropaleontology Bullettin, v. 28. pp. 1-159.

Sprovieri, R., D'Agostino, S. and Di Stefano, E., 1973, Giacitura del Calabriano nei dintorni di Catanzaro: Riv. Italiana di Paleontologia, v. 79, pp. 27-140.

Sprovieri R., Di Stefano E., Howell M., Sakamoto T., Di Stefano A. and Marino M., 1998, Integrated calcareous plankton biostratigraphy and cyclostratigraphy at Site 964: in Robertson, A.H.F., Emeis, K.C., Richter C. and Camerlenghi A. eds, Proc. ODP, Sci. Results v. 160, pp. 155-165. College Station, TX (Ocean Drilling Program).

Stefanelli, S., 2004, Cyclic changes in oxygenation based on foraminiferal microhabitats: Early-Middle Pleistocene, Lucania Basin (southern Italy) Journal of Micropaleontology, v. 23, pp. 81-95.

Suguio, K., Sallun, A. E. M. and Soares E. A. A., 2005, Quaternary: "Quo Vadis"?. Episodes, v. 28, 3, pp.197-200.

Tauxe, L., Opdyke, N.D., Pasini, G.C. and Elmi, C., 1983, Age of the PlioPleistocene boundary in the Vrica section, Southern Italy: Nature, v. 304 pp. 125-129.

Thunnell, R., Williams, D., Tappa, E., Rio, D. and Raffi I., 1990, PliocenePleistocene Stable Isotope Record for Ocean Drilling Program Site 653, Tyrrhenian Basin: Implication for the Paleoenvironmental History of the Mediterranean Sea, in Kastens, K.A., Mascle, J., et al., eds, Proc. ODP Sc. Result., v. 107, pp. 387-399. College Station, TX (Ocean Drilling Program)

Vai, G.B., 1996, Revisione critico-storica dei piani marini del Quaternario. Servizio Geologico Italiano, Miscellanea, VI, pp. 1-179.

Van Couvering, J., 1995, Setting Pleistocene marine stages: Geotimes, v. 40, pp. $10-11$

Van Couvering, J.A., 1997 (ed.), The Pleistocene Boundary and the Beginning of the Quaternary. Cambridge University Press, pp. 1-296.

Van Couvering J.A, Berggren W.A., Drake R.E., Aguirre E., Curtis G.H., 1976. The Miocene Terminal Event. Marine Micropaleontology, v. 1, pp. 263-286.

Van Couvering, J.A., Castradori, D., Cita, M.B., Hilgen, F.J. and Rio, D., 2000, The base of the Zanclean Stage and of the Pliocene Series. Episodes, v. 23, 3, pp. 179-186.

Zachariasse, W.J., Gudjonsson, L., Hilgen, F.J., Langereis, C.G., Lourens, L.J., Verhallen, P.J.J.M. and Zijderveld, J.D.A., 1990, Late Gauss to early Matuyama invasions of Neogloboquadrina atlantica in the Mediterranean and associated record of climatic change: Paleoceanography, v. 5 , pp. 239-252.

Zahn, R., Comas, M.C., and Klaus, A. (Eds.), 1999, Proc. ODP, Sci. Results, 161: College Station, TX (Ocean Drilling Program).

Zijderveld, J.D.A., Langereis, C.G., Hilgen, F.J., Verhallen, P.J.J.M. and Zachariasse W.J., 1991, Integrated magnetostratigraphy and biostratigraphy of the upper Pliocene-lower Pleistocene from the Monte Singa and Crotone areas in southern Calabria (Italy): Earth Planet. Sci. Lett., v. 107, pp.697-714.
Maria Cita is Emeritus of Geology at the University of Milano, Italy, and chair of the International Commission on Stratigraphy, Subcommission on Stratigraphic Classification and of the Italian Commission on Stratigraphy. An expert in Marine Geology and in Mediterranean Neogene, she served several times as shipboard scientist in the early days of the Ocean Drilling Program (Legs 2, 13, 40, 47) and has been Project Leader of IGCP Project 96 'Messinian Correlation' (key-Project, 1975-79). Honorary Fellow of GSA, Honorary Member of INQUA and of the Italian Paleontological Society, member of several academies, she has chaired the Geological Society of Italy, AIQUA, ESCO (Sci.Com.European Consortium Ocean Drilling) and the Neogene Subcommission of the International Commission on Stratigraphy.

Enrico Di Stefano is Associate Professor of Paleontology and Micropaleontology at the University of Palermo, where he specialized in calcareous nannofossils. Invited as shipboard scientist on ODP Leg 160 in the central and eastern Mediterranean, he contributed in particular to the precise correlation of Quaternary pelagic continously cored successions. His research is focused on biostratigraphy, chronostratigraphy, paleoecology and paleoclimatology of the last 25 my of the Mediterranean area.

Gianbattista Vai is Professor of Geology and Stratigraphy at the University of Bologna and has been a member of the IGCP Board (198086). He has been a member of several subcommissions of the International Commission on Stratigraphy: Silurian Subcommission (1964-72), Devonian Subcommission (1974-90), Quaternary Subcommission (19952000), Neogene Subcommission (2000-present). His research interests are broad and multiple, spanning from Paleozoic stratigraphy and regional geology of the Carnian Alps to Messinian evaporitic facies, the anatomy of the Apenninic Mountain Chain, History of Geology, Thematic maps, Principles of stratigraphic nomenclature, Quaternary stratigraphy.
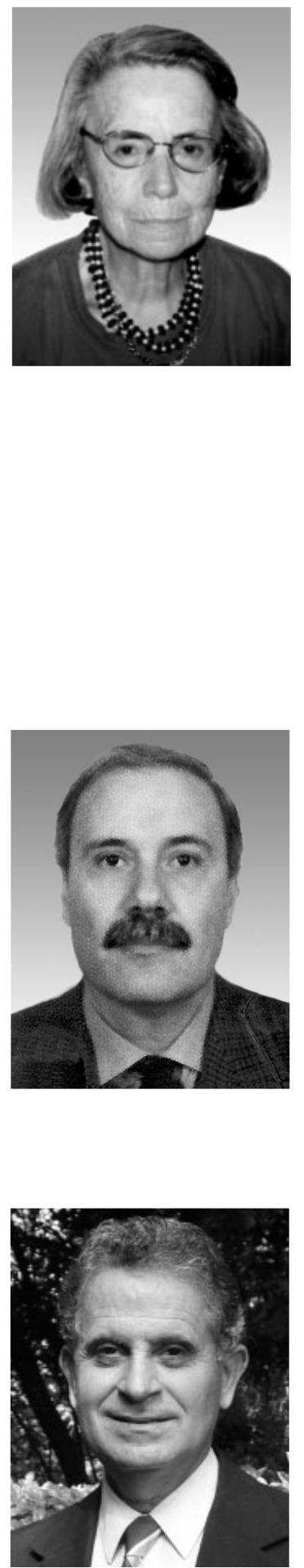